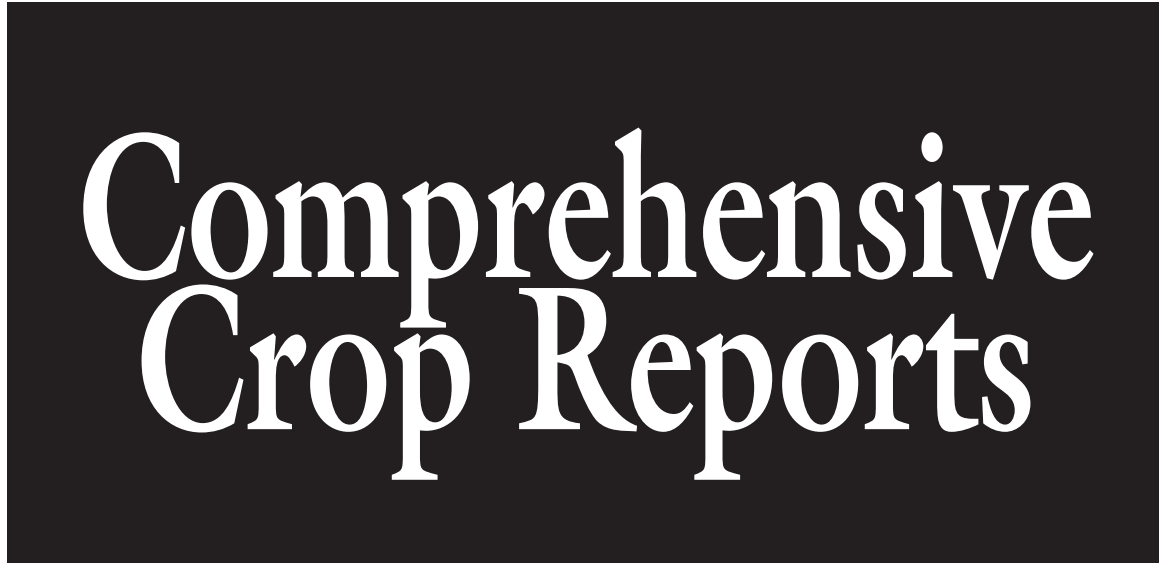

\title{
Bleeding Heart: A Review for Growers
}

\section{Laurie Hodges ${ }^{1}$}

AdDitional INDEX wORDs. Dicentra spectabilis, Lamprocapnos spectabilis, perennial, cut flower, floriculture, breeding

SuMmaRY. A favorite garden flower for centuries, bleeding heart or old-fashioned bleeding heart (Lamprocapnos spectabilis) is also used as a potted plant and in floral arrangements. Most general gardening guides include information on growing conditions but provide few specifics regarding plant growth and development that are important to those interested in commercial cultivation and use in the floral industry. Although uncommon in the U.S. floral industry, the plant is adaptable for use as a flowering potted plant and as cut floral stems with potential for year-around availability. This report provides detailed cultural information for this audience with an overview of the history of the species and its unique characteristics. Despite the popularity of the spectacular flower and plant form, until 1997 it was only available in the common pink and white form or a pure white form and exhibited little phenotypic variability. Three new cultivars, Goldheart, Valentine, and Hordival, are now available with distinctive foliage and flower colors. These new cultivars are poised to create much interest among gardeners and cut flower growers. The history, culture, propagation, forced flowering, use as a cut flower, pest management, and pharmacological potential are presented.

$\mathrm{T}$ The old-fashioned bleeding heart (Dicentra spectabilis) from northeast Asia was recently reclassified as Lamprocapnos spectabilis in the family Fumariaceae based on DNA sequencing and differences in pollen and seed coat anatomy from other Fumariaceae (Liden et al., 1997). The former Latin name, Dicentra spectabilis, translates as "spectacular two spurs," while Lamprocapnos means "bright smoke," both referring to the flowers. It is a spectacular flower known for at least 2000 years for its beauty and for centuries as a garden plant (Zeiner, 2006). The plant has arching stems (racemes) of pink heart-shaped flowers that appear to bleed a drop of white

Department of Agronomy and Horticulture, 377 Plant Sciences Hall, University of Nebraska, Lincoln, NE 68583-0724

${ }^{1}$ Corresponding author. E-mail: lhodges1@unl.edu. blood. The leaves are coarsely dissected, blue-green, with a fern-like appearance. The flowering stem and flowers are in two planes of symmetry making them particularly attractive and easy to incorporate into floral designs. At the base of each outer pink petal is a spur, which holds nectar from glands at the base of the stamens. Plants flower over a 3- to 4-week period in late spring, with anthesis starting between late April and early June through the north temperate zones.
Bleeding heart is native to the cool, moist woodlands of northeastern Asia, growing in dappled shade. It does not bloom well in dense shade and will not tolerate poorly drained soils, especially in the winter. It is adapted to U.S. Department of Agriculture hardiness zones 2 to 9. Plants can tolerate more sun in the more northern latitudes if kept reliably moist. Partial shade is required in the south or where summer temperatures are high. High, diffuse light under cool, moist, well-drained conditions in a neutral to slightly alkaline soil high in humus are optimal conditions. Plants need to be protected from wind. Plants can form clumps $1 \mathrm{~m}$ across and almost as tall. Anecdotal reports indicate stems approaching $2 \mathrm{~m}$ height. If plants are cut back in midsummer, no new leaves will form (Hanchek, 1989), whereas cutting flowering stems in the spring will result in new floral racemes developing from axillary buds on the stem or from crown buds. Once growing, long photoperiods of $18 \mathrm{~h}$ promote growth and flowering indefinitely, especially when combined with a periodic cutting back of plants to promote new flushes of growth (Hanchek, 1989; Weiler and Lopes, 1977).

\section{History}

Bleeding heart is native to southeastern Siberia, Korea, and the northern areas of China. Grown in Chinese gardens and as a forced potted plant for hundreds of years, it was first seen by Western scientist Linnaeus in 1765 as a drawing in a student thesis. Although it was mentioned in European literature as early as 1804 and was present in England as early as 1812, these introductions died out before becoming established (Tebbitt et al., 2008). Successful introduction into European gardens followed its reintroduction in 1846 by Robert Fortune on his return to England from a collecting trip to China for the Royal Horticultural Society. Fortune

\begin{tabular}{llll}
\hline $\begin{array}{l}\text { Units } \\
\begin{array}{l}\text { To convert U.S. to SI, } \\
\text { multiply by }\end{array}\end{array}$ & U.S. unit & SI unit & $\begin{array}{l}\text { To convert SI to U.S., } \\
\text { multiply by }\end{array}$ \\
\hline 0.3048 & $\mathrm{ft}$ & $\mathrm{m}$ & 3.2808 \\
3.7854 & $\mathrm{gal}$ & $\mathrm{L}$ & 0.2642 \\
2.54 & inch(es) & $\mathrm{cm}$ & 0.3937 \\
1 & $\mathrm{ppm}$ & $\mathrm{mg} \cdot \mathrm{kg}^{-1}$ & 1 \\
1 & $\mathrm{ppm}$ & $\mathrm{mg} \cdot \mathrm{L}^{-1}$ & 1 \\
$\left({ }^{\circ} \mathrm{F}-32\right) \div 1.8$ & ${ }^{\circ} \mathrm{F}$ & ${ }^{\circ} \mathrm{C}$ & $\left(1.8 \times{ }^{\circ} \mathrm{C}\right)+32$
\end{tabular}


purchased the plant from a nursery in Shanghai. It flowered in England in May 1847 (Fortune, 1847). By 1852, it had appeared in North America and throughout Europe, primarily as a forced pot plant in the conservatory. It was believed not to be frost tolerant, despite Fortune predicting it to be so, and crowns were dug from the garden after the foliage died down and brought inside, where they typically flowered in February, being returned to the garden in May. By 1878, the garden adaptability of the plant was well recognized and it was one of the top six garden plants in England (Coats, 1968). Plants were advertised for sixpence (6d) in 1882 in England (Gardening Illustrated, 1882), equivalent to $\approx £ 13$ or U.S. $\$ 22$ in today's buying power. The white-flowered bleeding heart (L. spectabilis var. alba) was first mentioned in the Proceedings of the Royal Horticultural Society in 1864 noting its blush white color and origin from China (Royal Horticultural Society, 1864), which is the earliest known reference to this color form. No information regarding the original source, wild or cultivated, of the white-flowered plant is known. Early white-flowered clones may have been different from the plant we know today as the flowers were reported to be tinged with pink and the plants much weaker than the red-flowered clones (Tebbitt et al., 2008; Williams, 1903). Although commonly grown in gardens worldwide, bleeding heart recently was included in a proposed list of threatened crop plants because of its potential uses in pharmacology and the relatively few endemic populations known within its historic range (Hammer and Khoshbakht, 2005).

\section{Plant growth and development}

Bleeding heart has a spreading, tuberous root system which overwinters. These large, cylindrical roots consist largely of starch-filled parenchyma cells, which provide nutrients for spring growth. During the growing season, a mass of fibrous roots also develops from the crown (Ignatyeva, 2000; Stern, 1961; Williams, 1903). Crown buds are formed in late summer on the tuberous roots at the base of the previous year's growth. In a Michigan study, crown buds developed rapidly between 11 and 26 Sept., followed by bud maturation evidenced by bud elongation, increased dry weight, or both through mid-November (Hanchek, 1989). Unlike many dormant buds, each lateral bud scale contains both a vegetative and reproductive meristem. The terminal bud scale contains only foliage meristems (Williams, 1903). A cold period is not required for differentiation of the floral meristem but is required for stem elongation in the spring. Gibberellic acid cannot substitute for the cold period (Lopes and Weiler, 1977; Song et al., 2003; Weiler and Lopes, 1976).

Crown buds form vegetative shoots that have solid stems and reproductive stems that are hollow. The sap is watery. Some people have an allergic reaction to the sap, which is high in isoquinolines and other alkaloids that make the plant toxic (Israilov et al., 1984; Stern, 1961). When planting crowns, buds should be 2.5 to $5 \mathrm{~cm}$ below the soil surface. Bleeding heart benefits from excellent nutrition during its vegetative period aboveground. Only general recommendations for culture in the landscape have been reported for bleeding heart (Armitage, 2008; Tebbitt et al., 2008). Soil should be well-drained and moderately fertile. Well-rotted manure or compost may be added to provide nutrients and to improve soil structure. Addition of phosphorous in the form of bonemeal or wood ashes from deciduous hardwood trees is recommended by Tebbitt et al. (2008). Typical of many geophytes, nutrients likely are translocated from senescing foliage to the crown and tuberous storage roots, which continue to accumulate nutrients as long as the fibrous roots remain functional. Roots continue to grow for several months after the tops have died back as long as the soil maintains warmth and moderate moisture. Thus, plants benefit from an annual top dressing in the fall or early spring with compost or aged manure as long as there is good drainage. Poor drainage, especially in winter, will kill the plant. For pot culture, a general recommendation would be a complete fertilizer rate of 200 to $250 \mathrm{ppm}$ for both nitrogen and potassium on a constant feed program (Nau, 1996).

Many authors mention a summer resting period when the stems dieback. This is a response to moisture stress rather than a heat- or daylengthinduced dormancy. If adequate soil moisture is maintained consistently, plants remain vegetative and may flower until fall when dormancy is induced by a photoperiod of $14 \mathrm{~h}$ or less (Tebbitt et al., 2008; Weiler and Lopes, 1985). Native to eastern Siberia, northern China, and Korea, bleeding heart does not tolerate high temperatures well; however, temperature does not induce dormancy. Plants left to dieback naturally in response to short days are larger and have more flowering stems the following spring. We have cut as many as 25 flowering stems per plant from 3 -year-old plants started as two- to three-eye divisions in 5-gal pots when kept moist and left to dieback naturally in the fall (L. Hodges, unpublished data).

Apparently, a hardening effect takes place in the field in the fall that affects dormancy and regrowth in the spring. During cold storage, plants dug before the first week of November developed considerable mold and poor regrowth in a Michigan study (Hanchek, 1989; Hanchek and Cameron, 1995). Digging crowns in early winter and storing them at $0{ }^{\circ} \mathrm{C}$ for 4 months resulted in higher quality plants that were taller, had more vigorous regrowth, and were more likely to flower when forced (Hanchek, 1989). Time from potting to first flower was most rapid, averaging $\approx 3$ weeks, for plants harvested later in the fall and stored for 4 months (Hanchek, 1989) although others report good growth after 8 to 12 weeks of storage at $5{ }^{\circ} \mathrm{C}$ (Lopes and Weiler, 1977). If a cold storage facility is not available, potted plants can be overwintered outside. In a northern climate, use of a laminated polyethylene foam blanket provided excellent protection of potted fringed or fernleaf bleeding heart (Dicentra exima) and doubled survival compared with no cover (Fisher, 2001). Similar results could be expected with bleeding heart. Where winter temperatures fall below $-10{ }^{\circ} \mathrm{F}$ or where there are high winds, the recommendation is to use a double layer of foam frost blanket or place the potted plants inside an unheated greenhouse or high tunnel under a single or double layer of foam frost blanket (Fisher, 2001).

\section{Forced flowering}

After the appropriate cold period, bleeding hearts can be forced easily for cut flowers or grown as potted plants. The ideal temperature for forcing is 10 to $12{ }^{\circ} \mathrm{C}$. If warmer, 
stem quality suffers (Lopes and Weiler, 1977). The expansion of the flowers and the number of flowers per raceme are greater with supplemental lighting (Lopes and Weiler, 1977). Although often considered a shade plant, higher light intensities result in greater root growth and earlier flowering than low light intensities, which, when sufficiently low, may result in flower abortion (Lopes and Weiler, 1977; Mallberg, 2004; Weiler and Lopes, 1976). Forcing bleeding hearts has been practiced since they were first introduced and was practiced in Asia before introduction to Europe. Live plants in England first flowered in May 1847 as forced potted plants (Fortune, 1847). It never caught on in America as much as in England, even as late as 1928 (Bailey, 1928). Garden plants are dug in late October, divided so that each division has several eyes, roots trimmed as needed to fit into pots, and the potted plants kept in cold storage or buried in the soil outside. In early January, pots are moved inside to a sunny window sill or cool greenhouse. It is more common now to start with either two- to threeeye or three- to five-eye divisions from the cold storage of a wholesale supplier. When potting divisions, up to $50 \%$ of the root mass can be pruned away without significantly affecting subsequent growth or flowering (Weiler and Kirk, 1984). Maintaining moderately moist soil is most important because of the rapid growth of the plant, which will normally flower within 1 month. Under controlled conditions, plants flower 3 to 4 weeks after planting at $11{ }^{\circ} \mathrm{C}$ night temperature and 2 to 3 weeks after planting at a $15^{\circ} \mathrm{C}$ night temperature (Weiler and Lopes, 1985). The shoots are cut off after flowering and the plant moved to a cool spot until spring when it can be planted outside. New growth often will include some flowering stems.

Forcing crowns for sale as potted plants has been the subject of several research projects. For container production, a short, compact plant is desired. Plants are stocky when grown at short photoperiods of 14 to $15 \mathrm{~h}$ of light. Plant growth regulators must be applied immediately after shoot growth is initiated and again $5 \mathrm{~d}$ later because of uneven shoot emergence. Daminozide at 3000 ppm or paclobutrazol at $50 \mathrm{ppm}$ provided the best plant size, color, and inflorescence (Kim et al., 1999). Immature flowers that develop on cut stems after harvest or as flowers mature on potted plants often are lighter in color and the color of open flowers will fade before senescence. If potted plants are treated with additional light, or cut flowering stems are treated before harvest with silver thiosulfate (STS), plant height/stem length increases slightly, more flowers open, and color retention is improved (Roberts et al., 1995). Fading of flowers is less noticeable for the white form compared with the red (Mallberg, 2004).

\section{Cut flower}

The graceful form of bleeding heart has been admired as a cut flower for centuries. Plants in the garden normally flower for $\approx 4$ weeks starting as early as late April to June, key months in the U.S. floral business. Bleeding heart stems can be cut when the first heart is fully open although often those cut by growers for local markets or those harvested for personal use are not harvested until three or more flowers are fully open. It is desirable to have at least five flowers on a stem; seven to 12 is common.

Marketable stems from first year two- to three-eye crowns from cold storage averaged $35 \mathrm{~cm}$ long from the cut stem to the first open flower (Mallberg, 2004). When harvested with one flower on the raceme fully open, the other flowers will develop normally when stems are placed in a commercial floral preservative. The white-flowered form does not have quite the same arching raceme as the red-flowered form, tending to be either more vertical or horizontal than the pure arch of the red cultivar.

Bleeding hearts are recognized as ethylene sensitive (Stevens, 1998), and STS treatment prolongs vase life (Roberts et al., 1995). Our research found that floral preservatives extended the average vase life for red-flowered bleeding heart from 8 to $12 \mathrm{~d}$ and from 8 to $17 \mathrm{~d}$ for the white-flowered form, compared with vase life in water (Mallberg, 2004). Vase life of the red bleeding heart stems stored at $2{ }^{\circ} \mathrm{C}$ in floral preservative gradually decreased from an average of $7 \mathrm{~d}$ after $16 \mathrm{~d}$ of storage to $\approx 4 \mathrm{~d}$ when kept in cold storage for $25 \mathrm{~d}$ (Mallberg, 2004). Best conditions for flowering and stem length are summarized in Table 1.

\section{Propagation}

Plants do not self-pollinate and require pollination by a different clone to set seed. When conditions in the garden are appropriately cool and moist with humus-rich soil and plants of different clones are in close proximity, self-seeded plants may be considered a nuisance. Pollination is primarily by bumblebees (Bombus sp.) seeking nectar and a few other pollinators with a long proboscis (Ignatyeva, 2000; Stern, 1961). Seeds mature in midsummer and are dispersed by ants (Formicidae) attracted to small structures on the seeds called elaiosomes containing fats (Fig. 1). The ants gather the seeds and bring them back to their nests to consume the elaiosome thereby dispersing the seeds locally. This restricted distribution likely contributed to the evolutionary isolation and speciation within the family. Seeds generally are fertile and require a warm period followed by a cold and moist stratification followed by second warm period for maturation and germination. Seeds

Table 1. Best conditions for bleeding heart flowering and stem length.

Cool, moist root zone during initial growth; $13{ }^{\circ} \mathrm{C}\left(55.4^{\circ} \mathrm{F}\right)$ is ideal

Well-drained, moist soil with humus and high organic matter content

High, diffuse light for more flowers per stem

Wind protection

16 to $18 \mathrm{~h}$ of light for longer stems

15 to 20 weeks of chilling at $5^{\circ} \mathrm{C}$

$\left(41.0^{\circ} \mathrm{F}\right)$ or colder to break dormancy and promote stem elongation

Avoid drought or waterlogged soil

Allow stems to dieback naturally in the fall when daylight is less than $14 \mathrm{~h}$

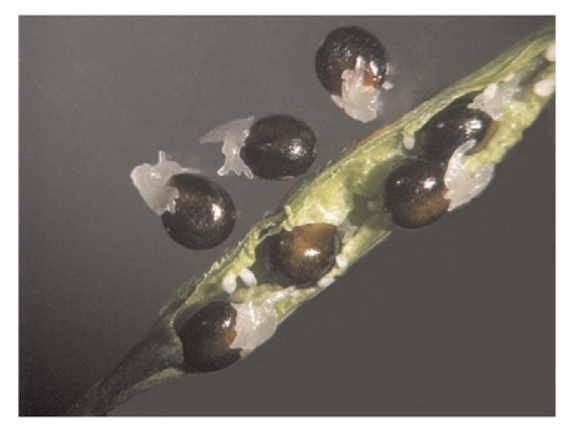

Fig. 1. Seeds of bleeding heart with white elaiosomes. 
freshly harvested in late spring can be germinated by sowing into a flat containing a peat-based lightweight germination mix and placing the flat into a coldframe, keeping the mixture slightly moist. Germination will occur the following spring. Alternatively, cold stratify the seeds in the moist media for 6 to 8 weeks at $4{ }^{\circ} \mathrm{C}$, then move the seedling tray to a place with light and cool temperatures ( 15 to $18^{\circ} \mathrm{C}$ ) for another 2 to 4 weeks. Repeated stratification may result in germination of additional dormant seeds. Once seeds have germinated, the young plants can be divided carefully in the spring or after the leaves have died down. Gibberellic acid (25-100 ppm $\mathrm{GA}_{3}$ or $\mathrm{GA}_{4+7}$ ) can increase the percent germination (Kim and Chung, 2001; Kim and Um, 1995 ), which is rarely more than $60 \%$ and often erratic (Nau, 1996). Seedlings will first flower during their second year (Nau, 1996).

Plants can be pinched and terminal vegetative cuttings rooted in a 1 peat: 1 perlite mix (by volume) although propagation by root division is more common. Year-around culture of bleeding heart is feasible through production of stock plants using rooted cuttings with both the propagation and growth of the plants in long photoperiods. Vegetative cuttings root best when taken in the spring from young growth and placed in moist perlite or vermiculite in a humid atmosphere or under mist. It may take a month for roots to form. Rooting hormone is not necessary. Root cuttings can be made from tuberous roots in the spring or fall by taking a 7.5- to $10-\mathrm{cm}$ section of a root and inserting it into a moist peat:perlite mixture (Armitage, 2008). Crown divisions are normally made in the fall but also can be made in very early spring before budbreak. Most bleeding hearts in the trade now are reproduced vegetatively by dividing the crown into two- to three-eye or threeto five-eye divisions. To store divisions (crowns) over the winter, it is important that they do not dry out; however, bleeding heart is very susceptible to mold during storage, especially if harvested before full dormancy in the fall (Hanchek, 1989; Maqbool and Cameron, 1994). From crowns harvested in November, the best method found was to pack the crowns in slightly moist 1 peat: 1 perlite mix (by volume) in crates lined with polyethylene plastic in a cooler maintained between 1 and $4{ }^{\circ} \mathrm{C}$ (Cameron and Maqbool, 1986).

Tissue culture techniques were published in 1982 (Lazarz et al., 1982). Tissue culture is not used commercially to propagate bleeding heart because of the ease of crown division and rooting cuttings.

\section{Pest management}

Bleeding hearts have few pest problems. Thrips (Thripidae) may damage flowers and occasionally whiteflies (Aleyrodidae) will be a problem in a greenhouse crop, but few other insects affect the plant. Slugs and snails (Gastropoda) may eat new growth. Bleeding hearts are not bothered by rabbits (Leporidae) or deer (Cervidae). Fusarium wilt (Fusarium sp.), viruses, and fungal leaf spots (Stemphyllium) can occur. A phytoplasma infection can result in a proliferation of shoots or witches broom effect. It is also susceptible to southern blight (Sclerotium rolfsii). Occurrence of gray mold ( $\mathrm{Bo}^{-}$ trytis cinerea) can be a problem during storage of the cut stems, which can be reduced with good air circulation. Of disease pathogens, viruses are most commonly seen. Plants can be infected with tobacco rattle tobravirus, tobacco ringspot nepovirus, tobacco mosaic virus, ribgrass mosaic virus, and the aster yellows phytoplasma (Gill et al., 2006; Lane, 2006; L. Lane, personal communication).

Tobacco rattle virus is the most devastating of the various viruses that infect bleeding heart. First found in bleeding heart in the United States in 2000 , it is a systemic virus, leading

inevitably to plant decline and death (Lockhart, 2000). Symptoms often are evident only under cool conditions. It is transmitted via the root nematodes, Paratrichodorus and Trichodorus. Since many herbaceous perennials are propagated by division, the incidence of diseased plant material is increasing and it is increasingly common in purchased crowns (Lockhart, 2000).

Possible causes of various problems observed on bleeding heart plants are in Table 2.

Weeds may be a problem in larger field production systems or landscape plantings. Crown buds are close to the soil surface and root damage will shorten the life of the plant so it is best to avoid cultivation. Generally, few broadleaf weeds develop in the shade under bleeding heart plants. The few reports located on chemical weed control indicate that bleeding heart is tolerant of oxadiazon, oryzalin, trifluralin, napropamide, and dacthal. It does not tolerate diuron or simazine (Bateman, 1971; Didario, 1961; Schuett and Klett, 1989; Tichknor, 1960).

\section{Breeding and selection}

Old-fashioned bleeding heart is now recognized as evolutionarily distinct from all other types of bleeding hearts including those in the genus Dicentra such as dutchman's breeches (D. cucullaria) or fernleaf bleeding heart, also known as pacific bleeding heart (D. formosa). It does not cross with any other genus in the Fumariaceae family (Stern and Ownbey, 1971; Tebbitt et al., 2008). Thus, the white-flowered form discussed above is apparently a rare natural mutant discovered before 1846,

Table 2. Production problems affecting bleeding heart and possible causes.

Problem Possible cause

Flower abortion, few flowers per stem

Flowers on very short stems or

flowers without stem elongation

Plant dies back soon after flowering

Plant fails to emerge in spring

Dark, mushy stems at soil line

Mosaic, circles, or other patterns on the foliage; crinkled foliage
Too warm; insufficient chilling; too much shade

Insufficient chilling time or temperatures; high temperatures during stem elongation

Drought; too much shade

Tobacco rattle mosaic virus; crown decay due to excess moisture

Bacterial rot due to poor drainage; waterlogged soil overwinter; white mold (Sclerotinium rolfsii) if white threads of mold present with small, hard, round pellets (sclerotia)

One or more viruses 
perhaps with subsequent selection for pure white color and improved vigor. It sets viable seeds. There are reports by several authors of a white cultivar called Pantaloons, but no original citation or source of this cultivar has been located and it may be either a trade name or common name (Paghat, n.d.). The cultivar Goldheart became available in 1997. 'Goldheart' has broad, bright yellowgold leaves in the spring on peachcolored stems. The gold color of the leaves is most intense when grown in moderate shade and may have merit as cut foliage. By midsummer, the leaves are lime green. It is a strong grower, performing best in moist soil and moderate shade as the leaves may sunburn in full sun. The flowers are the traditional rose pink and white. Although sometimes listed as a hybrid, the cultivar Goldheart is actually a selection first propagated in 1993 from a mutant offshoot of the standard species by Nori Pope of Hadspen House in England. 'Goldheart' possibly was the second cultivar selected from the species in over 1000 years.

How this came about is an interesting story. Pope noticed a small spot on the leaf of a regular pinkflowered bleeding heart plant. $\mathrm{He}$ watched it for a few days and then decided to propagate it by cutting out the spot, removing the parenchyma cells, and grafting the cells into an apical bud on the plant and then putting the entire plant into a sweat box to see if the graft would take. A few weeks later, a small, pale yellow shoot appeared. As additional green shoots appeared from the base, they were cut out until the shoot was entirely a clear and consistent yellow. As this shoot developed, cuttings were taken and sent away to be tissue cultured. The new cultivar was named 'Goldheart' and was introduced to the trade in 1997 (N. Pope, personal communication).

In 2009, a fourth cultivar of bleeding heart named Valentine was released to the trade. With deep red flowers on dark burgundy stems, it is slightly more compact than the species, averaging $65-\mathrm{cm}$ tall and wide with darker green foliage. 'Valentine' was discovered as a chance seedling by Lyle and Phyllis Sarrazin in Prince George, BC, Canada, and released by Hortis Holland (Rijswijk, The Netherlands) in 2009 with plant breeder rights (Flowerweb, 2010; Verschoor, n.d.). In 2011, the Sarrazins filed a patent application for another bleeding heart seedling discovered in 2005 with orange-red flowers, which is named 'Hordival' (Sarrazin and Sarrazin, 2011). It also is slightly shorter and more compact than the wild species. It also has dark red stems. Since a natural hybrid is not possible and variation is very limited in this old species, traditional breeding of new cultivars has been slow. In Korea, techniques were recently developed using somatic regeneration with the intent to develop new commercial cultivars of this flower through genetic transformation (Lee and Lee, 2003).

\section{Pharmacologic potential}

Dicentra sp. and L. spectabilis are closely related to poppies (Papaver sp.) and share many of the chemicals associated with the poppy family (Papaveraceae) (Israilov et al., 1984). Bleeding heart has a history of ethnopharmaceutical use in Asian cultures and was listed as a botanical drug in the United States as early as 1880 (Nickell, 1880). Recent pharmacological investigations of the various alkaloids found in bleeding heart include potential in a natural antiaging serum (Lee et al., 2004), as fungicides (Ma et al., 2000), as antidepressants, and as anticancer agents (McNulty et al., 2007).

\section{Conclusion}

The popularity of bleeding heart in the landscape has not yet become associated with it as a potted plant or a specialty cut flower. Research has provided the knowledge required to successfully force this stunning plant to bloom at any time of the year and to manipulate plant height and stem length. Postharvest handling to ensure cut stem vase life of more than a week as well as longevity of display for potted plants has been determined. The additional flower and foliage colors found in the first new cultivars in over 150 years may stimulate interest in this spectacular and evocative flower, fostering development of new market opportunities.

\section{Literature cited}

Armitage, A.M. 2008. Herbaceous perennial plants: A treatise on their identification, culture, and garden attributes. 3rd ed. Stipes Publ., Champaign, IL.
Bailey, L.H. 1928. The standard cyclopedia of horticulture. Vol 1. MacMillan, New York.

Bateman, G. 1971. Herbicides on herbaceous plants. Gardeners Chronicle 169: 24-26.

Cameron, A.C. and M. Maqbool. 1986. Postharvest storage of bare-root hardy perennials: The relation of water loss to storage survival. Acta Hort. 181:323-329.

Coats, A.M. 1968. Flowers and their histories. A\&C. Black, London.

Didario, A. 1961. Evaluation of dacthal in ornamentals. Proc. 14th Southern Weed Conf. p. 158-163.

Fisher, P. 2001. Overwintering perennials in containers. 7 Sept. 2010. <http:// extension.unh.edu/Agric/AGGHFL/ Overwntr.pdf>.

Flowerweb. 2010. Plantarium novelties 2010. 18 Nov. 2011. <http://nm.flowerweb. $\mathrm{nl} / \mathrm{prg} /$ newsmaker? GBN_UNIQUE= 20100924_115317880_235472\&FIRM= FLOWERWEB \&LNG=NL\&DP=show text\&TXT_DIR $=/$ en $/$ news $/ \& T X T \_I D=$ 20100824_215524725_583175\&edit_ mode $=\mathrm{NO}>$.

Fortune, R. 1847. Dielytra spectabilis, a new plant introduced from China. Royal Hort Soc. 2:178.

Gardening Illustrated. 1882. Gardening Illustrated 4:ii.

Gill, S., R.A. Cloyd, J.R. Baker, D.L. Clement, and E. Dutky. 2006. Pests and diseases of herbaceous perennials: The biological approach. 2nd ed. Ball Publ., West Chicago, IL.

Hammer, K. and K. Khoshbakht. 2005. Towards a 'red list' for crop plant species. Genet. Resources Crop Evol. 52:249-265.

Hanchek, A.M. 1989. Growth and development of Dicentra spectabilis in relation to storage temperature and harvest date. Michigan State Univ., East Lansing, PhD Diss.

Hanchek, A.M. and A.C. Cameron. 1995. Harvest date and storage quality of herbaceous perennials. HortScience 30:573576.

Ignatyeva, I.P. 2000. Ontogenetic morphogenesis in vegetative organs of dicentra magnifiscent [sic] (Dicentra spectabilis (L.) Lem. (in Russian). Izvestiya Timiryazevskoi Sel'skokhozyaistvennoi Akademii 1:42-66.

Israilov, F., M. Melikov, and D.A. Murav'eva. 1984. Alkaloids of Dicentra. Chem. Nat. Compd. 20:74-76.

Kim, G. and T. Um. 1995. A study for the utilization of wild herbaceous speciesEffects of gibberellic acid treatment of seed germination. J. Korean Appl. Ecol. 9:56-61. 
Kim, H. and J. Chung. 2001. Effects of $\mathrm{GA}_{3}$, moist-chilling storage and removal of funiculus on the germination of Dicentra spectabilis. Korean J. Hort. Sci. Technol. 19:78-80.

Kim, S., A.A. DeHertogh, and P.V. Nelson. 1999. Effects of plant growth regulators applied as sprays or media drenches on forcing of Dutch-grown bleeding heart as a flowering potted plant. HortTechnology 9:629-633.

Lane, L. 2006. TRV symptoms on Dicentra spectabilis. 22 Aug. 2007. <http://lclane. net/text/trv.html>.

Lazarz, S.A., M.R. Zillis, and K.C. Sink. 1982. In vitro propagation of Dicentra spectabilis. HortScience 17:188-189.

Lee, D-H., B-C. Lee, E-J. Yoon, K-E. Leem, S-M. Park, H-B. Pyo, and T-B. Choe. 2004. Development of effects of plant extracts on the activity and expression of UVA-induced MMPs (matrix metalloproteases). Intl. J. Cosmet. Sci. 26:319, (abstr.).

Lee, K.P. and D.W. Lee. 2003. Somatic embryogenesis and plant regeneration from seeds of wild Dicentra spectabilis (L.) Lem. Plant Cell Rpt. 22:105-109.

Liden, M., T. Fukuhara, J. Rylander, and B. Oxelman. 1997. Phylogeny and classification of Fumariaceae, with emphasis on Dicentra s. 1., based on the plastid gene rpsl6 intron. Plant Syst. Evol. 206:411420.

Lockhart, B.E.L. 2000. Dicentra, Epimedium, and Heuchera: New perennial ornamental hosts of tobacco rattle virus in the United States. Plant Dis. 84:1344.

Lopes, L.C. and T.C. Weiler. 1977. Light and temperature effects on the growth and flowering of Dicentra spectabilis (L.) Lem. J. Amer. Soc. Hort. Sci. 102:388-390.

Ma, W-G., Y. Fukuski, S. Tahara, and T. Osawa. 2000. Fungitoxic alkaloids from Hokkaido Papaveraceae. Fitoterapia 71:527-534.
Mallberg, I.L. 2004. Forcing Dicentra spectabilis (L.) Lem. as a specialty cut flower. Univ. of Nebraska, Lincoln, MS Thesis.

Maqbool, M. and A.C. Cameron. 1994. Regrowth performance of field-grown herbaceous perennials following bareroot storage between -10 and $+5 \mathrm{C}$. HortScience 29:1039-1041.

McNulty, J., J. Poloczek, V. Larichev, N.H. Werstiuk, C. Griffin, and S. Pandey. 2007. Discovery of the apoptosis-inducing activity and high accumulation of the butenolides, menisdaurilide and aquilegiolide in Dicentra spectabilis. Planta Med. 73:1543-1547.

Nau, J. 1996. Ball perennial manual: Propagation and production. Ball Publ., West Chicago, IL.

Nickell, J.M. 1880. Botanical ready reference. Cameron, Amberg \& Co., Chicago.

Paghat. (n.d.). Paghat's garden: Dicentra spectabilis 'alba'. 3 May 2011. <http:// www.paghat.com/bleedingheartalba. html>.

Roberts, C.M., M. Serek, and A.S. Andersen. 1995. Supplemental irradiance and STS improve the display life of Dicentra species forced as flowering potted plants. Sci. Hort. 62:121-128.

Royal Horticultural Society. 1864. Royal Hort. Soc. Proc. 2/4:96.

Sarrazin, L. and P. Sarrazin. 2011. Dicentra plant named 'Hordival'. U.S. Patent Application 20110296573. 15 Jan. 2012. <http://www.google.com/patents/ US20110296573>.

Schuett, J. and J.E. Klett. 1989. Preemergent weed control in containergrown herbaceous perennials. J. Environ. Hort. 7:14-16.

Song, J.S., C.S. Bang, and Y.D. Chang. 2003. Effects of cold and $\mathrm{GA}_{3}$ treatment of flowering of eight perennials native to Korea. Acta Hort. 62:267-272.
Stern, K.R. 1961. Revision of Dicentra (Fumariaceae). Brittonia 13:1-57.

Stern, K.R. and M. Ownbey. 1971. Hybridization and cytotaxonomy of Dicentra. Amer. J. Bot. 58:861-866.

Stevens, A.B. 1998. Field grown cut flowers: A practical guide and sourcebook. 2nd ed. Avatar's World, Edgerton, WI.

Tebbitt, M., M. Liden, and H. Zetterlund. 2008. Bleeding hearts, corydalis, and their relatives. Brooklyn Botanic Garden/Timber Press, Portland, OR.

Tichknor, R.L. 1960. Ornamental and nursery crops. 9th Ann. Oregon Weed Conf. p. 35-36.

Verschoor, J.(n.d.). Dicentra. 14 Nov. 2011. <http://www.verschoorperennials. com/dicentrastories $>$.

Weiler, T.C. and T.I. Kirk. 1984. Regulating bleeding hearts for Valentine's Day. Florists' Rev. 19:48-50.

Weiler, T.C. and L.C. Lopes. 1976. Photoregulated Dicentra spectabilis (L.) Lem. as a potential potted plant. Acta Hort. 64:191-195.

Weiler, T.C. and L.C. Lopes. 1977. Photo and thermo-regulation of growth and flowering in Dicentra spectabilis (L.). Lem. Acta Hort 68:121-124.

Weiler, T.C. and L.C. Lopes. 1985. Dicentra spectabilis, p. 92-94. In: A.H. Halevy (ed.). Handbook of flowering. Vol. 5. CRC Press, Boca Raton, FL.

Williams, C. 1903. A study of the development of Dicentra spectabilis and allied species. Univ. of Kentucky, Lexington, MS Thesis.

Zeiner, H.M. 2006. Exotics of Colorado: Bleeding heart, Dicentra spectabilis. Rocky Mountain News 21 Nov. 2006. 